\title{
PARAMETRIC STUDY OF LOCA IN TRIGA-2000 USING RELAP5/SCDAP CODE
}

\author{
Anhar R. Antariksawan, Surip Widodo, Hendro Tjahjono \\ Center for Nuclear Reactor Safety and Technology, BATAN \\ Building 80, Puspiptek area, Serpong, Tangerang Selatan 15314 \\ Email: anhar@batan.go.id \\ Diterima editor: 7 Maret 2017 \\ Diperbaiki: 31 Maret 2017 \\ Disetujui untuk publikasi: 4 April 2017
}

\begin{abstract}
PARAMETRIC STUDY OF LOCA IN TRIGA-2000 USING RELAP5/SCDAP CODE. A postulated loss of coolant accident (LOCA) shall be analyzed to assure the safety of a research reactor. The analysis of such accident could be performed using best estimate thermal-hydraulic codes, such as RELAP5. This study focuses on analysis of LOCA in TRIGA-2000 due to pipe and beam tube break. The objective is to understand the effect of break size and the actuating time of the emergency core cooling system (ECCS) on the accident consequences and to assess the safety of the reactor. The analysis is performed using RELAP/SCDAPSIM codes. Three different break size and actuating time were studied. The results confirmed that the larger break size, the faster coolant blow down. But, the siphon break holes could prevent the core from risk of dry out due to siphoning effect in case of pipe break. In case of beam tube rupture, the ECCS is able to delay the fuel temperature increased where the late actuation of the ECCS could delay longer. It could be concluded that the safety of the reactor is kept during LOCA throughout the duration time studied. However, to assure the integrity of the fuel for the long term, the cooling system after ECCS last should be considered.
\end{abstract}

Keywords: safety analysis, LOCA, TRIGA, RELAP5

\begin{abstract}
ABSTRAK
STUDI PARAMETRIK LOCA DI TRIGA-2000 MENGGUNAKAN RELAP5/SCDAP. Kecelakaan kehilangan air pendingin (LOCA) harus dianalisis untuk menjamin keselamatan suatu reaktor riset. Analisis LOCA dapat dilakukan menggunakan perhitungan best-estimate seperti RELAP5. Penelitian ini menekankan pada analisis LOCA di TRIGA-2000 akibat pecahnya pipa dan tabung berkas. Tujuan penelitian adalah memahami efek ukuran kebocoran dan waktu aktuasi sistem pendingin teras darurat (ECCS) pada sekuensi kejadian dan mengkaji keselamatan reaktor. Analisis dilakukan menggunakan program perhitungan RELAP/SCDAPSIM. Tiga ukuran kebocoran dan waktu aktuasi ECCS berbeda dipilih sebagai parameter dalam studi ini. Hasil perhitungan mengonfirmasi bahwa semakin besar ukuran kebocoran, semakin cepat pengosongan tangki reaktor. Lubang siphon breaker dapat mencegah air terkuras dalam hal kebocoran pada pipa. Sedang dalam hal kebocoran pada beam tube, ECCS mampu memperlambat kenaikan temperatur bahan bakar. Dari studi ini dapat disimpulkan bahwa keselamatan reaktor dapat terjaga pada kejadian LOCA, namun pendinginan jangka panjang perlu dipertimbangkan untuk menjaga integritas bahan bakar.
\end{abstract}

Kata kunci: analisis keselamatan, LOCA, TRIGA, RELAP5 


\section{INTRODUCTION}

A research reactor has an important role in the research and development of nuclear science and technology. To date, there are 244 research reactors with various types in the world [1]. One type of the most constructed is TRIGA (Training, Research, Isotopes by General Atomic), which is designed and constructed by the General Atomic. Indonesia has two research reactors with TRIGA type, namely TRIGA-2000 and Kartini research reactor.

The safety of any nuclear installation, including a research reactor, shall be the priority for the operator of those installations. The detailed demonstration of the safety of research reactor is in general provided in the Safety Analysis Report (SAR). This SAR shall include safety analysis of various probable accident sequences and features incorporated in the design to avoid, minimize the likelihood or to mitigate the consequences [2]. Safety analysis for a nuclear reactor, especially thermal-hydraulic aspect of safety analysis, is generally performed using computational tools. Many of these computational tools or codes are initially developed for a nuclear power reactor, such as RELAP5, ATHLET and CATHARE codes. However, several study have been done to assess the applicability of these codes for different type of research reactors, especially MTR type [3-6], TRIGA type [7], and also for other nuclear test facilities [8, 9].

A series of study on the applicability of RELAP5 for IPR-R1 TRIGA reactor with $250 \mathrm{~kW}$ of thermal power has been performed. The RELAP5 model developed for IPR-R1 reactor showed a good agreement with the experimental data for $50 \mathrm{~kW}$ steady state, but not for loss of flow transient condition [10]. The improvement of the model by dividing the reactor pool into two regions with a cross flow model between both regions showed a better transient calculation result [7]. A sensitivity study on the core model of IPR-R1 showed that better coolant temperature prediction was obtained with increasing number of core channels and cross flow models [11]. An analysis of the loss of coolant accident in IPR-R1 TRIGA reactor due to reactor tank break and without reactor scram was performed, as well. The model predicted the fast increase of fuel and coolant temperature following such extreme hypothetical accident [12]. The validity of the RELAP5 model was also assessed using Oregon State TRIGA Reactor of $1 \mathrm{MW}$ thermal power [13]. The steady state calculation has been done and has shown a good agreement with the measurement.

On the other hand, the study to assess the applicability of the RELAP5 model to TRIGA2000 reactor was also done [14]. The steady state and loss of flow transient were performed [15]. The comparison with the measurements had still shown a quite large difference, though the model could depict the natural circulation phenomena following loss of flow due to pump trip. Improvement of the model has been done. The improved model showed a good results for steady state condition, which agreed well with the measurements [16]. In that study, the loss of coolant accident (LOCA) in TRIGA-2000 was also analyzed. The model could describe a reasonable thermal-hydraulic characteristics of the reactor following two worst cases of pipe break and beam tube rupture. However, the previous study did not study the effect of the break size and the respond time of Emergency Core Cooling System (ECCS), which are important to be understood in the context of the emergency procedures and the reactor safety in general. Then, this current research will simulate and analyze the effect of the break size of pipe and beam tube and the role of the ECCS to keep the reactor safe. The objectives are to understand the event sequences in the core and reactor tank heat up, the optimum actuating time of the ECCS during hypothetical LOCA and the safety of TRIGA-2000 from LOCA event. The actuating time of the ECCS is assumed to be important because early actuation may be ineffective to the core cooling rather than the late actuation of the ECCS. The simulations were done using the RELAP5/SCDAP codes. The results are important in the context of the emergency operating procedures and could be benefited to TRIGA-2000 operator to improve their SAR.

\section{DESCRIPTION AND MODEL OF TRIGA-2000}

TRIGA-2000 reactor is TRIGA Mark-II reactor type. The initial power was $250 \mathrm{~kW}$, but then was upgraded to $2000 \mathrm{~kW}$ in year 2000. The fuel is cylindrical U-ZrH $\mathrm{rRIGA}_{\mathrm{x}}$ fuel with 
enrichment of $19.75 \%$. The reactor was cooled by light water. The core cooling is dominated by natural circulation. To transfer the heat to the secondary cooling system, the coolant is circulated to a plate type heat exchanger by a primary pump. The colder coolant then flows back to the reactor tank. Table 1 summarizes the main characteristics of the TRIGA-2000.

To mitigate the risk of LOCA, TRIGA-2000 reactor is equipped with ECCS. The ECCS would operate automatically when the coolant level in tank reaches $5 \mathrm{~m}$ below normal. The ECCS composes of a $15.5 \mathrm{~m}^{3}$ open water tank located at about $5.3 \mathrm{~m}$ height from the reactor deck, the piping system and water pouring ring which is located just above the chimney. The water will be poured gravitationally from the tank to the core through chimney when ECCS trip valve be opened by actuating system. There is also a simple passive safety system which is called siphon breaker holes located at both coolant inlet and outlet pipe which are submerged in the reactor tank. These holes are about $12.7 \mathrm{~mm}$ in diameter and at about $60 \mathrm{~cm}$ below the normal coolant level in reactor tank. The RELAP5 model of TRIGA-2000 cooling system and fuel are shown in Fig. 1. The Table 2 describes the nodalization of TRIGA-2000.

Table 1. Main characteristics of TRIGA-2000 [17]

\begin{tabular}{ll}
\hline Component & Characteristic \\
\hline Primary cooling & $\dot{m}_{\text {max }}: 950 \mathrm{gpm}(50.5 \mathrm{~kg} / \mathrm{s})$ \\
& $\mathrm{T}_{\text {in }}: 42.2{ }^{\circ} \mathrm{C}$ \\
& $\mathrm{T}_{\text {out }}: 32.2{ }^{\circ} \mathrm{C}$ \\
& $\dot{m}: 1200 \mathrm{gpm}(86.2 \mathrm{~kg} / \mathrm{s})$ \\
Secondary side cooling & $\mathrm{T}_{\text {out }}: 37{ }^{\circ} \mathrm{C}$ \\
& $\mathrm{T}_{\text {in }}: 29{ }^{\circ} \mathrm{C}$ \\
& Material : Aluminum \\
& Inner diameter: $14.24 \mathrm{~cm}$ \\
Pipes & Thickness : $0.5 \mathrm{~cm}$ \\
& Composition: $\mathrm{U}-\mathrm{ZrHx}$ \\
Fuel Element & Enrichment: $19.75 \% \pm 0.2 \%$ \\
& Total length: $72.0 \mathrm{~cm}$ \\
& Diameter: $37.5 \mathrm{~cm}$ \\
\hline
\end{tabular}

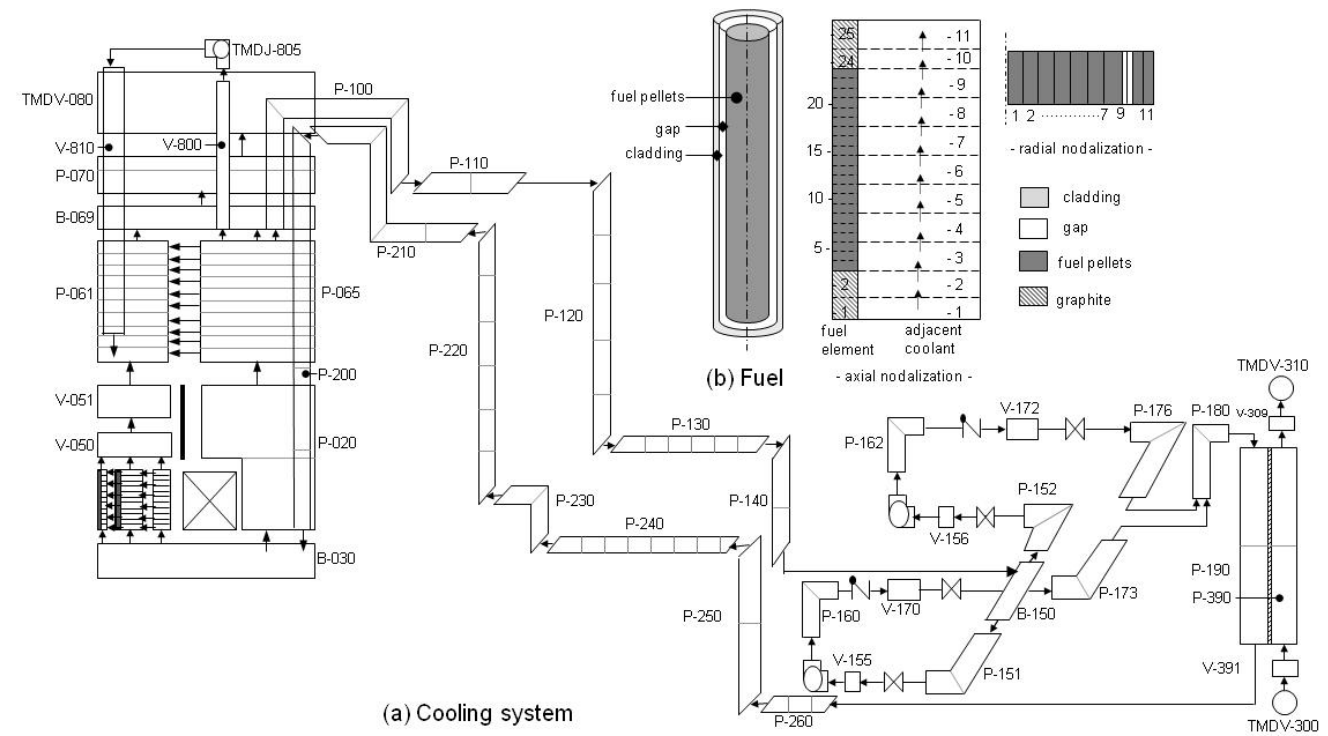

Fig. 1. Model and nodalization of TRIGA-2000 [16]. 


\section{METHODOLOGY}

The simulation used best-estimate thermal-hydraulic codes RELAP5/SCDAP. The code utilizes publicly available RELAP5/MOD3.3 and SCDAP/RELAP5/MOOD3.2 models. Each model has different features. The RELAP5 models calculate the overall thermal-hydraulic response, while the SCDAP models calculate the core and vessel behavior during normal and accident conditions [14]. The code has been validated for a wide range of reactor type, accident conditions using a variety of experiments and plant data including TMI-2 [9] and other test facility .

Table 2. Main system nodalization components and relative reference codes.

\begin{tabular}{|c|c|}
\hline Component & Reference Code \\
\hline Lower plenum & B030 \\
\hline Core by-pass channel & P020 \\
\hline Hot channel & P040 \\
\hline Average channel & P041 \\
\hline Cold channel & P042 \\
\hline Chimney & $\mathrm{B} 050$ and $\mathrm{V} 051$ \\
\hline \multicolumn{2}{|l|}{ Mixing pool } \\
\hline - Above core by-pass & P065 \\
\hline - Above chimney & P061 \\
\hline Upper plenum & V069 and V070 \\
\hline Pool atmosphere & TDV080 \\
\hline \multicolumn{2}{|l|}{ Heat exchanger } \\
\hline - Primary side & P190 \\
\hline - Secondary side & P390 \\
\hline Inlet primary pipe & P200-P260 \\
\hline Outlet primary pipe & P100-P180 \\
\hline Diffuser & P800, TDJ805, V810, P811 \\
\hline
\end{tabular}

The qualification of the model for TRIGA-2000 reactor, especially in the steady state condition, has been performed in the previous work [16]. In this current study, the transient calculations are performed for LOCA. Two events are considered, which are LOCA due to cold leg pipe break and one beam tube rupture. The cold leg break is located at the outlet of heat exchanger which is the lowest part of the piping system. In both cases, three different break size areas are studied, from $1 \%, 10 \%$ to $100 \%$ of the nominal cross section area of the pipe and beam tube, which are $0.018626 \mathrm{~m}^{2}$ and $0.02 \mathrm{~m}^{2}$, respectively. The $100 \%$ break size represents the worst case when the pipe or beam tube is guillotined break.

In the TRIGA-2000 SAR, ECCS is actuated when the level decreases $5 \mathrm{~m}$ below normal level [17]. However in this study, the different actuation time of ECCS would be investigated. There are three cases: ECCS starts to function when the water level downs to $5 \mathrm{~m}$ (case a, early actuation), to level of chimney (case b) and to the core top grid (case c, late actuation). The assessment of those different actuation times is aimed to assess the effectiveness of the ECCS for cooling the decay heat.

In all cases, it is assumed that the reactor scram occurred when the level decreases $50 \mathrm{~cm}$ below initial level. At the same time, the pump is stopped manually by the operator. As in the TRIGA-2000's SAR, the decay heat is calculated by the formula of Way-Wigner [17] as follow 


$$
\frac{P_{t}}{P_{0}}=6.22 \times 10^{-2}\left[t^{-0.2}-\left(t+T_{0}\right)^{-0.2}\right]
$$

where $P_{t}$ is the power at the time $t$ after shut down (MW), $P_{0}$ is the power before shut down (MW), $T_{0}$ is the duration of reactor operation prior to reactor shut down (s) and $t$ is time after shut down (s).

\section{RESULTS AND DISCUSSIONS}

\section{LOCA - Pipe Break}

Pipe break initiated at $500 \mathrm{~s}$ after steady state calculation has been started. Following the break, the coolant flew out through the break location and the coolant level in the reactor tank decreased. Fig. 2 shows the evolution of the coolant level in the reactor tank for three different break sizes. The level is measured from the bottom of the core. As in the Fig. 2, the velocity of the drain out is different for three cases; the water coolant level decreases faster when the size of break are larger. But, even in worst case, the leakage could be interrupted when the water level in the reactor tank passes around the siphon breaker holes, which is still far above the core. The siphon effect that could risk draining the water coolant up to the bottom of the core, because the end tip of the inlet pipe is at that level, could be avoided with the help of siphon breaker holes. It could be happened because air would penetrate through that holes and block the flow in pipe when the water level reaches the siphon breaker holes. However, it could also be seen that the final water level is different in three cases. In the case of $1 \%$ break size, the water level is almost at the level of the siphon breaker holes, but in the case of $100 \%$ break size, it is situated at about $60 \mathrm{~cm}$ below the siphon breaker holes. That is called overshooting height (OSH). OSH is defined as the difference between the final water level and the entrance of siphon breaker level [18]. The simulation results in this study are in agreement with the previous research where for a given size of siphon breaker hole, the overshooting height is proportional to the coolant leak flow rate [19, 20]. As the drained mass flow rate of coolant increases with the LOCA size, the OSH also increases with the LOCA size. The Table 3 and Fig. 3 show the decreasing of coolant velocity and OSH as a function of LOCA size, respectively. The linearity of the OSH with the water flow rate or LOCA size as shown in Fig. 3, is also indicated in previous research.

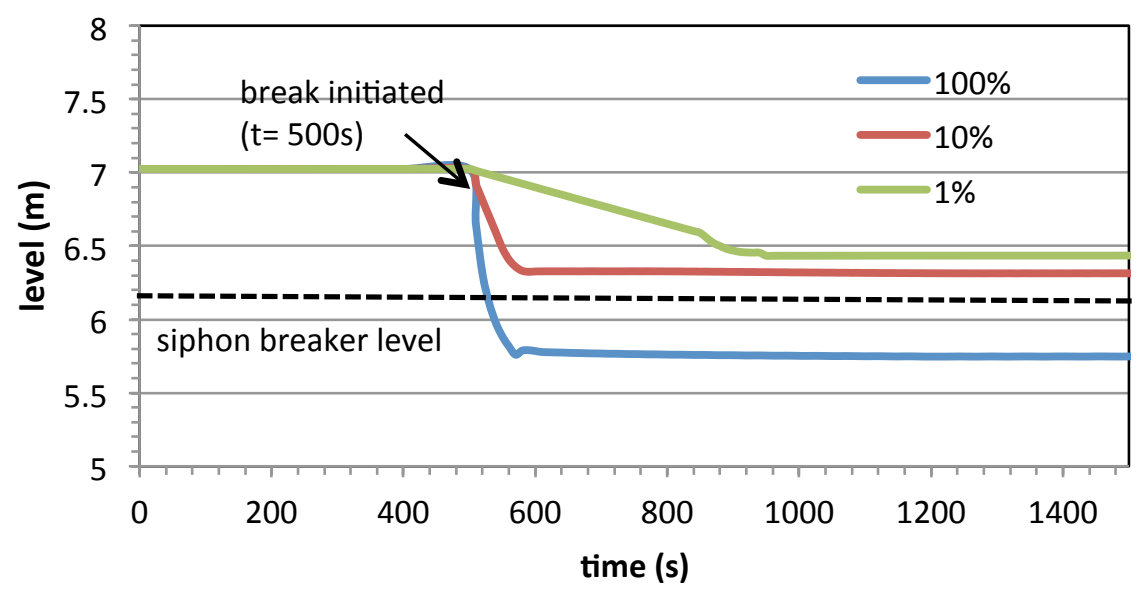

Fig. 2 The water level evolution during LOCA due to pipe break for three different break sizes.

Fig. 4 and 5 show the fuel and coolant temperature evolution during LOCA due to pipe break, respectively. With regard to the fuel temperature transient, as long as the reactor scram occurs, the fuel temperature is kept low, as in Fig. 4. The difference is only on time of scram (see 
Table 3); where the larger of LOCA size, then reactor scram will be faster. After reactor scram, the power decreases to the decay heat, then the fuel temperature decreases, as well. The coolant temperature decreases following the decrease of fuel temperature. In case of $100 \%$ break size, the coolant temperature drops significantly because the coolant from the upper part of reactor tank with lower temperature, i.e. approx. $37{ }^{\circ} \mathrm{C}$, falls to that level and mixes with the coolant in mixing region (see also Fig. 5). But, in the longer term after the leak terminated, the coolant temperature slightly increases again as the heat from the core is transferred to the remaining coolant by natural convection, as seen in Fig. 5.

Table 3. Main timelines of LOCA due to pipe break.

\begin{tabular}{lccc}
\hline \multirow{2}{*}{ Parameter } & \multicolumn{3}{c}{ Break size } \\
\cline { 2 - 4 } & $100 \%$ & $10 \%$ & $1 \%$ \\
\hline Time of break initiation (s) & 500 & 500 & 500 \\
Time of scram (s) & 511 & 540 & 850 \\
Time to leak stop (s) & 570 & 600 & 950 \\
Water level final height (m) & 5.76 & 6.32 & 6.43 \\
OSH (m) & 0.7 & 0.14 & 0.03 \\
Water level decrease velocity (m/s) & $2.22 \times 10^{-3}$ & $1.2 \times 10^{-3}$ & $0.63 \times 10^{-3}$ \\
\hline
\end{tabular}

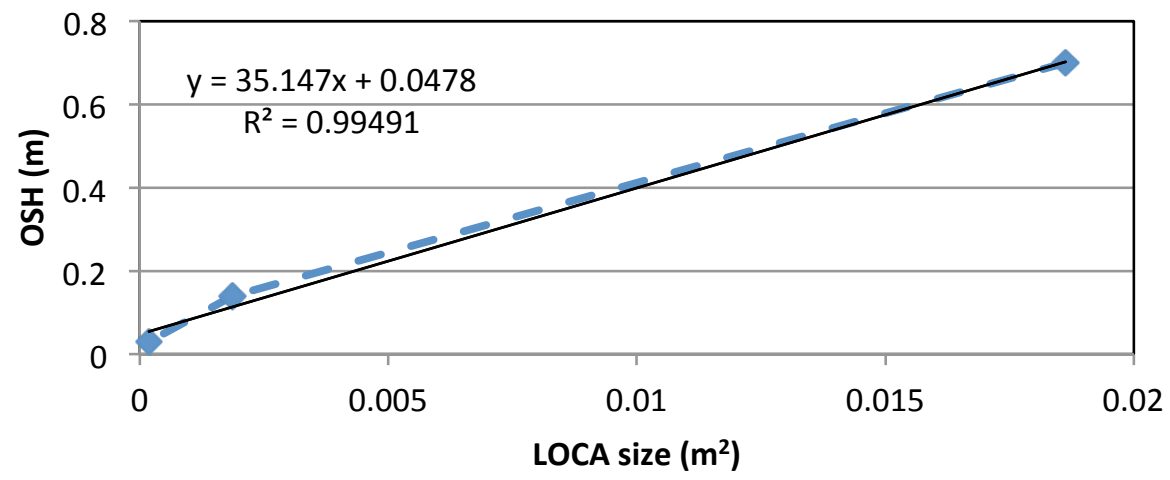

Fig. 3. OSH as function of LOCA size.

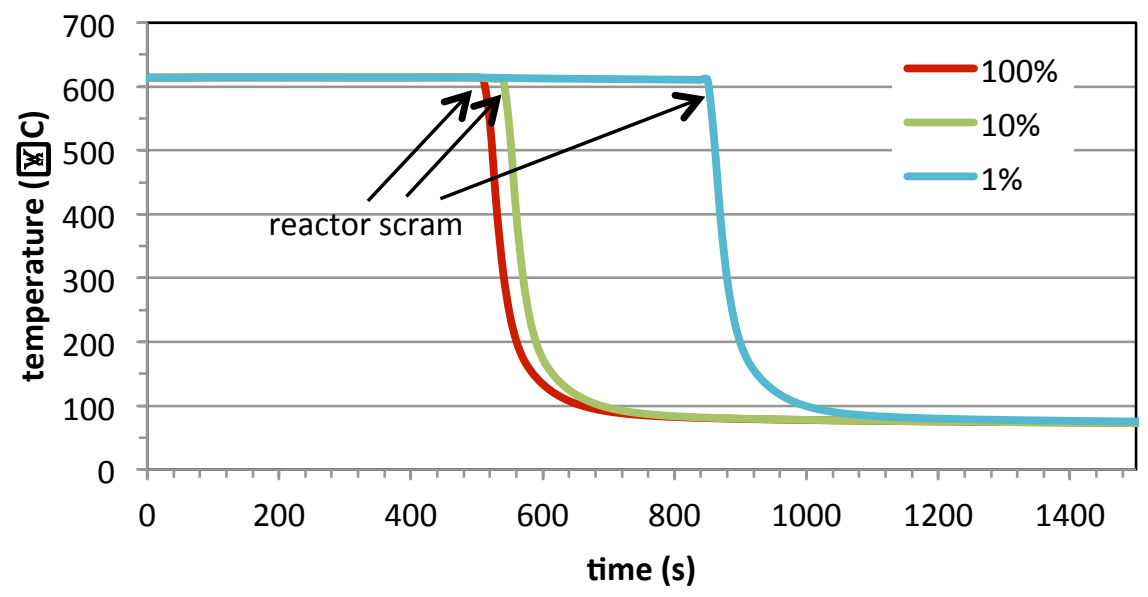

Fig. 4. Fuel temperature evolution during LOCA - pipe break for three different break sizes. 


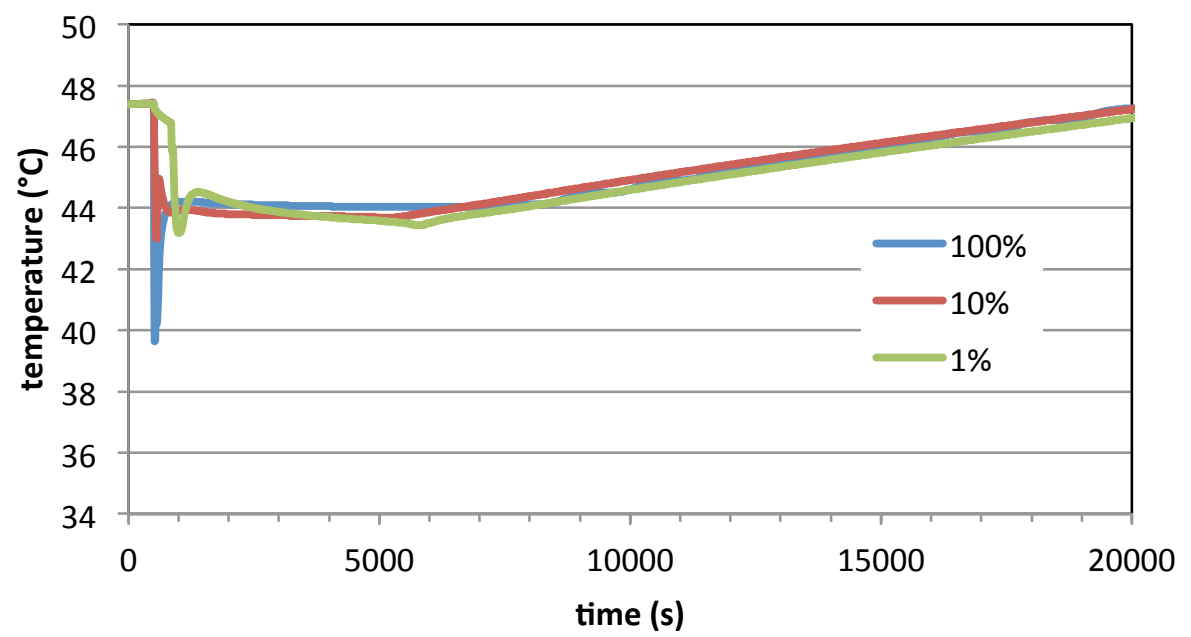

Fig. 5. Coolant temperature in mixing region during LOCA - pipe break for three different break sizes.

From the above results, it could be noted that in the case of LOCA due to pipe break, the siphon breaker holes could interrupt the siphon effect, which in turn could keep the core covered by the coolant serving to remove the heat via natural convection. In the other words, the size of the siphon breaker hole is adequate to break the siphon effect, even in the worst LOCA due to pipe break. However, in the long term, the external emergency cooling should be provided to anticipate the increasing of coolant temperature. The maximum OSH, which is proportional to the LOCA size, does not significantly affect the loss of coolant consequences.

\section{LOCA - Beam Tube Rupture}

Following the postulated beam tube rupture (inner diameter $16 \mathrm{~cm}$ ), the water flows out directly from the reactor tank to the reactor hall. Considering the beam tube is located at the middle height of the core, the reactor core may be uncovered. As the coolant level in reactor tank decreases $0.5 \mathrm{~m}$ from the initial level, scram signal is sent to the reactor protection system and reactor is automatically scram. At the same time, the pump is shutdown. While the coolant level attained $5 \mathrm{~m}$ below the initial level, the ECCS started to function by pouring gravitationally the water from ECCS tank to the reactor core. It should be noted from the previous study that without the ECCS, the fuel temperature rose quickly soon after the core uncovered. Table 4 shows the timelines of important event during LOCA due to beam tube rupture for all cases simulated.

Fig. 6 depicts the evolution of the water level during loss of coolant for different break size in case $\mathrm{c}$. It is obvious that larger break size causes faster water level decrease. It is interesting to note from that figure that in case of $1 \%$ break size, the water level increases again when the ECCS starts to pour the water. It is because the break size is quite small and as consequence, the water is accumulated in the core section. In two other cases, the water level continues to decrease up to the beam tube level due to higher leak flow than ECCS flow. As also seen in Table 4, larger break size causes faster scram and the function of the ECCS. Though the actuating time of the ECCS is different, but the period of ECCS function is the same at about 22,000 s. For a given break size, the actuation time of the ECCS tends to delay the water level to reach the beam tube level, but not for $100 \%$ break size.

The most important safety aspect is the fuel temperature. Fig. 7. shows the evolution of the fuel temperature in hot channel at the mid height (just in the beam tube level) and at top of fuel in case of $100 \%, 10 \%$ and $1 \%$ break size, respectively. The calculation was done for about $50,000 \mathrm{~s}$ (or about 14 hours). The time when ECCS starts and stops are also shown. In almost all cases, the ECCS could not prevent the fuel temperature increase. However, the ECCS could delay the increase of the fuel temperature as compared to the case of without the ECCS [16]. After about 14 
hours, the maximum temperature is still below the allowable maximum temperature of $970{ }^{\circ} \mathrm{C}[17]$. The increase of the fuel temperature is occurred when the ECCS flow lasted. In case of $100 \%$ break size, there is no effect of the actuation time of ECCS. But, in case of $10 \%$ and $1 \%$ break size, the latest actuation time of ECCS could delay the fuel temperature to increase. For the duration of calculation, the highest temperature is attained in the case of $10 \%$ break, i.e. approx. $700{ }^{\circ} \mathrm{C}$ in the top of fuel.

Table 4. Main timelines and features of LOCA due to beam tube rupture.

\begin{tabular}{|c|c|c|c|c|c|c|c|c|c|}
\hline \multirow{3}{*}{ Parameter } & \multicolumn{9}{|c|}{ Cases } \\
\hline & \multicolumn{3}{|c|}{$100 \%$} & \multicolumn{3}{|c|}{$10 \%$} & \multicolumn{3}{|c|}{$1 \%$} \\
\hline & (a) & (b) & (c) & (a) & (b) & (c) & (a) & (b) & (c) \\
\hline Time of rupture (s) & 500 & 500 & 500 & 500 & 500 & 500 & 500 & 500 & 500 \\
\hline Time of scram (s) & 510 & 510 & 510 & 596 & 596 & 596 & 1463 & 1463 & 1463 \\
\hline \multicolumn{10}{|l|}{ Time of ECCS operation (s) } \\
\hline - Start & 650 & 666 & 737 & 1891 & 2064 & 2710 & 14364 & 16090 & 22412 \\
\hline - Finish $*^{1}$ & 22900 & 22940 & 23020 & 24200 & 24550 & 25120 & 37180 & 38710 & 44630 \\
\hline $\begin{array}{l}\text { Time of water level reaches } \\
\text { beam tube level }(\mathrm{s}) *^{2}\end{array}$ & 810 & 810 & 820 & 10570 & 21570 & 22180 & 42820 & 43120 & 50380 \\
\hline $\begin{array}{l}\text { Time of fuel temperature } \\
\text { start to increase (s) }\end{array}$ & 17100 & 17100 & 17100 & 23500 & 23500 & 23500 & 40400 & 40720 & $\mathrm{No}^{* 3}$ \\
\hline
\end{tabular}

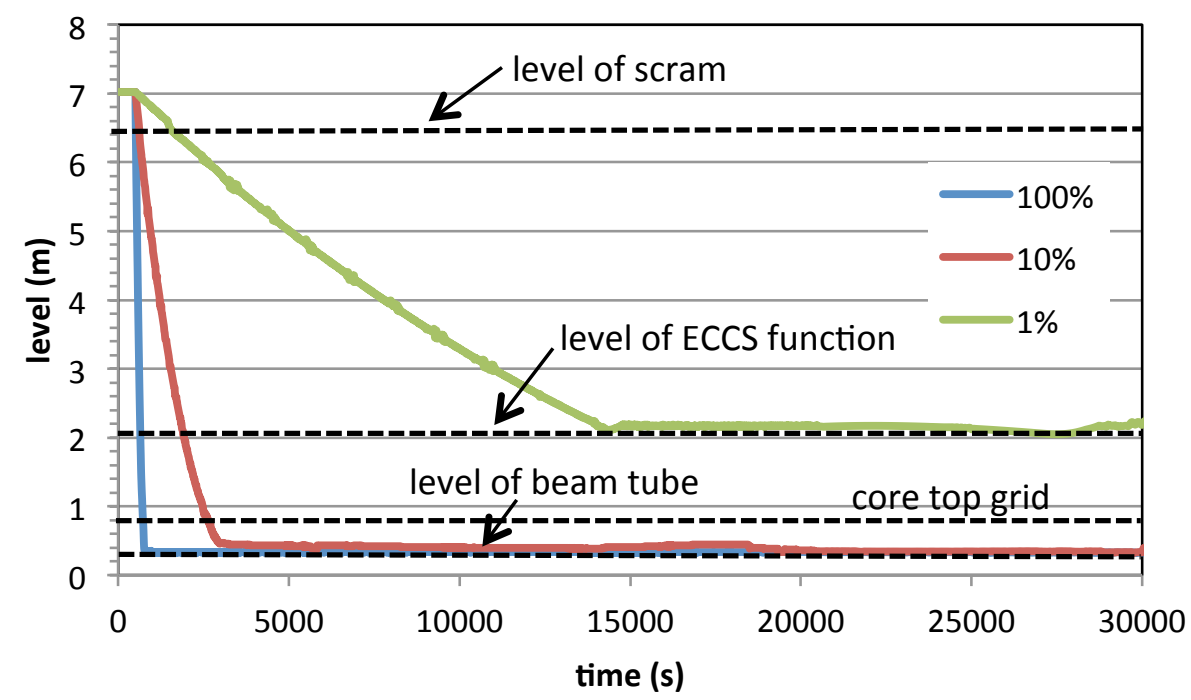

Fig. 6. Level of coolant evolution during LOCA - beam tube break for different break size. 

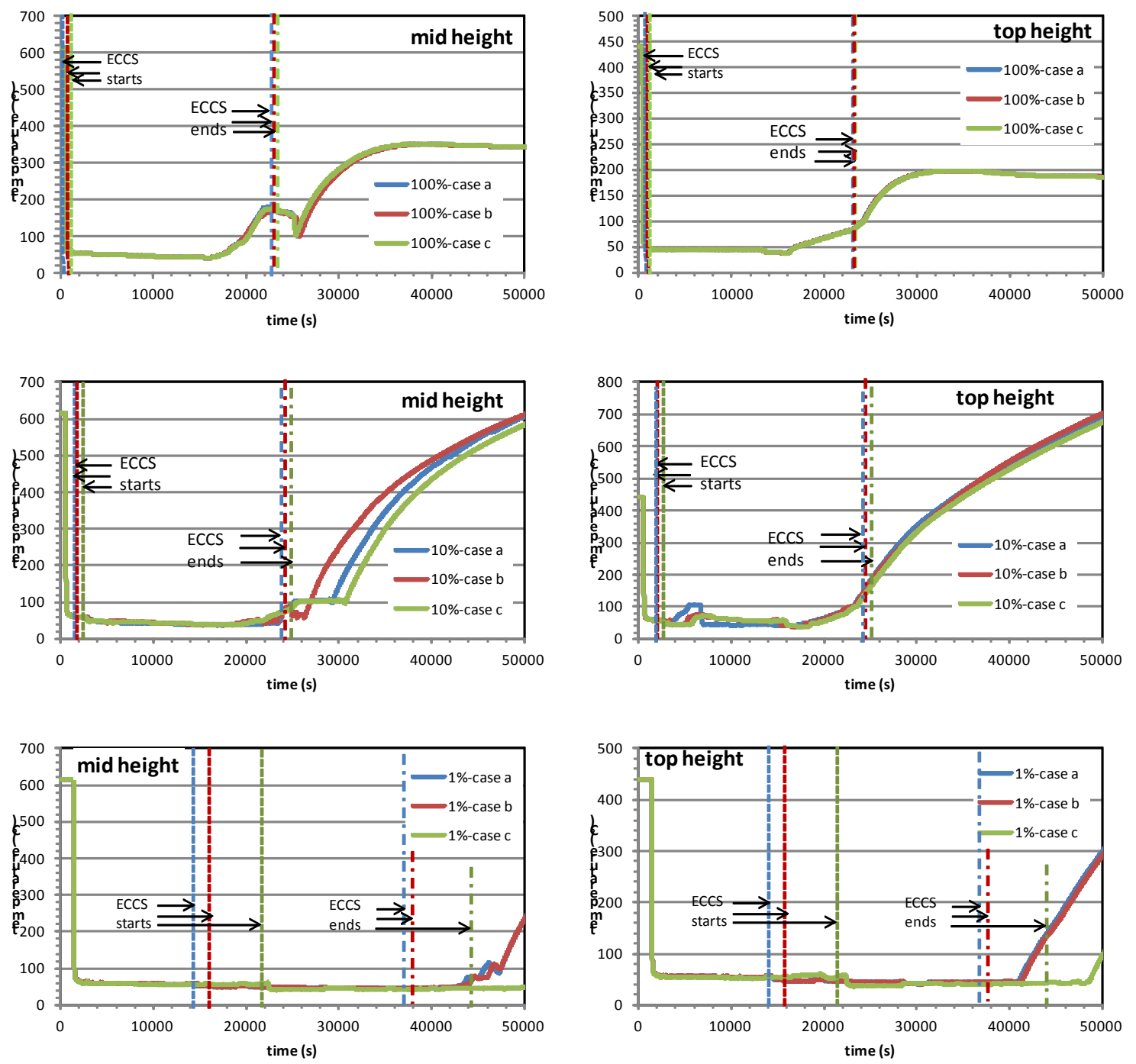

Fig. 7. Fuel temperature evolution for different break size and ECCS actuation time.

With regard to the long term cooling, especially after the ECCS is terminated, Fig. 8 shows the long term fuel temperature evolution in three different break sizes of LOCA with early actuation of ECCS. In the $100 \%$ break size, the fuel temperature could be kept about $350{ }^{\circ} \mathrm{C}$, but in the $10 \%$ and $1 \%$ break size, the fuel temperature increases continuously, especially at the uncovered part of fuel. This phenomenon is probably due to higher air cooling flow in case of larger break size, where the air flows to the core through broken beam tube to the atmosphere. A part of air cooling flow through the beam tube break, the expected air cooling flow through core by-pass to the core could have not happened because it has been blocked by the remaining water in the reactor tank which occupies the lower part of the tank, core and core by-pass section. The possibility of the core cooling by air flowing through the periphery of inner side of the chimney is not modeled in the current model. A further study could be considered for assessing that possibility. On the other hand, the simulation results also show that a long term cooling should be considered to avoid the increase of fuel temperature, especially in case of small break LOCA. 


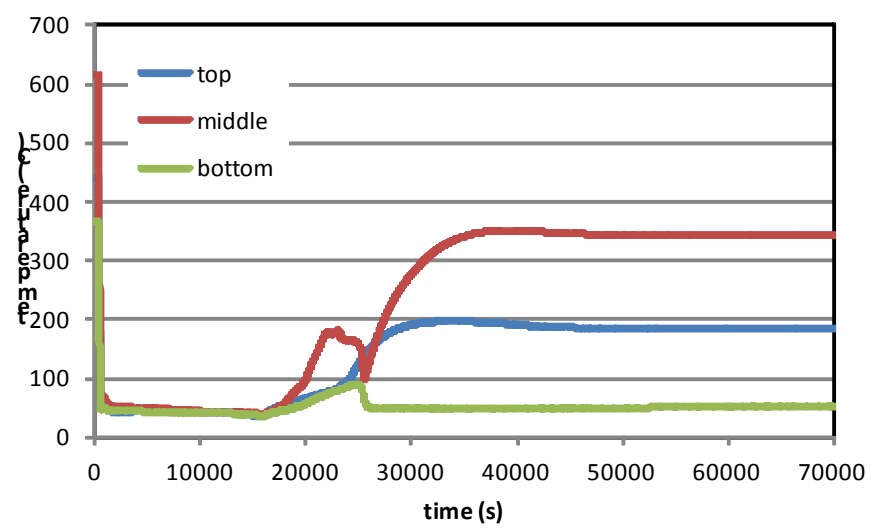

(a)

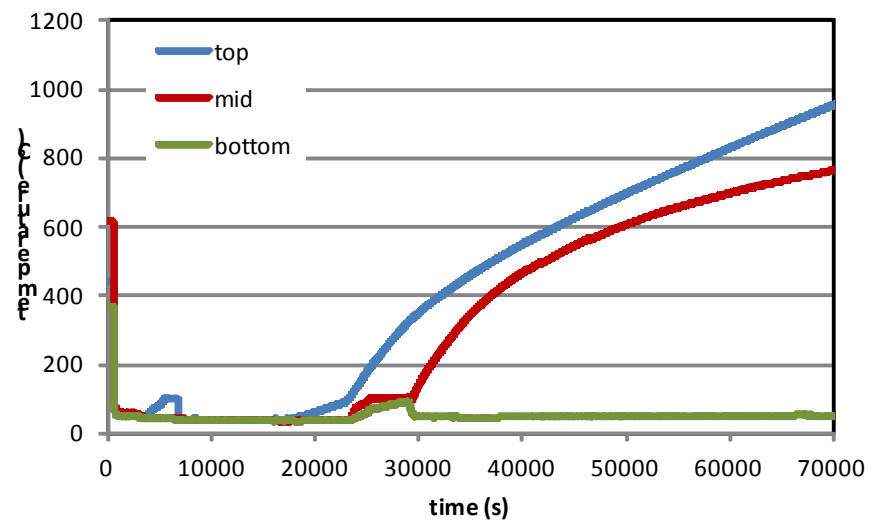

(b)

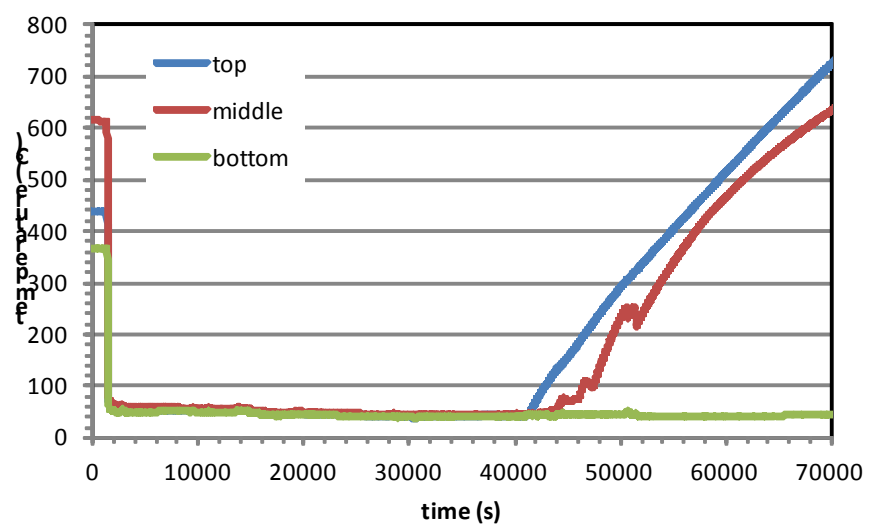

(c)

Fig. 8. The fuel temperature evolution during LOCA with early actuation of ECCS (a) $100 \%$ break size, (b) $10 \%$ break size and (c) $1 \%$ break size

\section{CONCLUSION}

A parametric study has been done to study the effect of break size and the actuating time of the ECCS during hypothetical LOCA in TRIGA-2000 reactor. The LOCA is due to pipe break and beam tube rupture. The study used RELAP/SCDAP codes to simulate the events. 
In case of LOCA due to pipe break, the siphon break holes are able to interrupt the siphoning effect and to keep the reactor coolant remains in the tank to cool the reactor core through natural convection. The break size has only the effect on OSH, which is still in an acceptable height, even in the case of the guillotine pipe break.

In case of LOCA due to one beam tube rupture, the study confirms the effect of break size on the rapidity of coolant drain out. The ECCS plays a role to delay the increase of fuel temperature, especially when the break size is relatively small. With regard to the actuation time of the ECCS, the operation of the ECCS at the time of water level at the top grid could delay the increase of fuel temperature rather than early operation of the ECCS, especially in small break size. However, during long term, the air cooling in case of larger break size could keep the fuel temperature in safe condition, but in smaller break size, the temperature continue to increase. The long term cooling should be considered.

Those above results have shown that the reactor safety is assured throughout the duration time studied. An external cooling should be considered to keep the integrity of the fuel from the risk of late increase of its temperature.

\section{ACKNOWLEDGEMENT}

The study is supported by BATAN as part of the research activity on safety analysis of research reactor of TRIGA-2000. Authors thank to colleagues from TRIGA-2000 reactor division for very helpful discussion.

\section{REFERENCES}

1. IAEA Research Reactor Data Base [Accessed: 8 February 2017]. Available from: http://nucleus.iaea.org.

2. IAEA Safety of Research Reactors, Specific Safety Requirements SSR-3. Vienna, Austria: 2016.

3. Soares H. V, Aronne I.D., Costa A.L., Pereira C., Veloso M.A.F. Analysis of Loss of Flow Events on Brazilian Multipurpose Reactor Using the RELAP5 Code. Sci. Technol. Nucl. Install. 2014.

4. Hainoun A., Doval A., Umbehaun P., Chatzidakis S., Ghazi N., Park S., et al. International benchmark study of advanced thermal hydraulic safety analysis codes against measurements on IEA-R1 research reactor. Nucl. Eng. Des. 2014. 280(January):233-50.

5. Chatzidakis S., Ikonomopoulos A., Ridikas D. Evaluation of RELAP5 / MOD3 behavior against loss of flow experimental results from two research reactor facilities. Nucl. Eng. Des. 2013. 255(1537):321-9.

6. Hedayat A., Davilu H., Jafari J. Loss of coolant accident analyses on Tehran research. Prog. Nucl. Energy. 2007. 49:511-28.

7. Reis P.A.L., Costa A.L., Pereira C., Veloso M.A.F., Mesquita A.Z., Soares H. V, et al. Assessment of a RELAP5 model for the IPR-R1 TRIGA research reactor. Ann. Nucl. Energy. 2010. 37:1341-50.

8. Kusuma M.H., Putra N., Antariksawan A.R., Susyadi, Imawan F.A. Investigation of the Thermal Performance of a Vertical Two-Phase Closed Thermosyphon as a Passive Cooling System for a Nuclear Reactor Spent Fuel Storage Pool. Nucl. Eng. Technol. 2016. Article in:4-11.

9. Allison C.M., Hohorst J.K. Role of RELAP / SCDAPSIM in Nuclear Safety. Sci. Technol. Nucl. Install. 2010.

10. Costa A.L., Amélia P., Reis L., Pereira C., Auxiliadora M., Veloso F., et al. Thermal hydraulic analysis of the IPR-R1 TRIGA research reactor using a RELAP5 model. Nucl. Eng. Des. 2010. 240:1487-94. 
11. Reis P.A.L., Costa A.L., Pereira C., Silva C.A.M., Auxiliadora M., Veloso F., et al. Sensitivity analysis to a RELAP5 nodalization developed for a typical TRIGA research reactor. Nucl. Eng. Des. 2012. 242:300-6.

12. Reis P.A.L., Costa A.L., Pereira C. Analysis of an extreme loss of coolant in the IPR-R1 TRIGA reactor using a RELAP5 model. Eng. Térmica (Thermal Eng. 2013. 12(2):46-50.

13. Marcum W.R., Woods B.G., Reese S.R. Experimental and theoretical comparison of fuel temperature and bulk coolant characteristics in the Oregon State TRIGA ${ }^{\circledR}$ reactor during steady state operation. Nucl. Eng. Des. 2010. 240:151-9.

14. Antariksawan A.R., Huda, Md Q, Liu, Tiancai, Zmitkova, J, Allison C.M., Hohorst J.K. Validation of RELAP5/ SCDAPSIM / Mod3 . 4 for research reactor applications. in: 13th International Conference on Nuclear Engineering. 2005. pp. 1-8.

15. Antariksawan A.R. Analysis of reactor coolant pump trip at TRIGA-2000 reactor using RELAP/SCDAPSIM/MOD3. 4 code. Tri Dasa Mega. 2007. 8(3):99-113. (in Indonesian)

16. Antariksawan A.R., Umar E., Widodo S., Juarsa M., Kusuma M.H. TRIGA-2000 research reactor thermal-hydraulic analysis using RELAP/SCDAPSIM/MOD3.4. Int. J. Technol. 2017.(under review)

17. BATAN Safety Analysis Report of TRIGA-2000 Bandung Reactor, RE-01-06. 2001.(in Indonesian)

18. Seo K., Ho S., Min J., Lee K., Jeong N., Chi D., et al. Experimental and numerical study for a siphon breaker design of a research reactor. Ann. Nucl. Energy. 2012. 50:94-102.

19. Kang S.H., Ahn H.S., Kim J.M., Joo H.M., Lee K., Seo K., et al. Experimental study of siphon breaking phenomenon in the real-scaled research reactor pool. Nucl. Eng. Des. 2013. 255:28-37.

20. Lee K., Kim W. Theoretical study on loss of coolant accident of a research reactor. Nucl. Eng. Des. 2016. 309:151-60. 